\title{
Meningkatkan Kemampuan Berbahasa Lisan pada Anak Usia Dini Melalui Media Gambar Berseri
}

\section{Ni Wayan Sri Wahyundari ${ }^{*}$, Dewa Ayu Puteri Handayani2}

\author{
1,2 Pendidikan Guru Pendidikan Anak Usia Dini, Universitas Pendidikan Ganesha, Singaraja, Indonesia
}

\section{ART I CLE I N F O}

Article history:

Received 26 January 2021

Revised 09 February 2021

Accepted 01 April 2021

Available online 25 April 2021

Kata Kunci:

Kemampuan Berbahasa, Media Pembelajaran, Pengembangan

\section{Keywords:}

Language Skills, Learning Media, Development

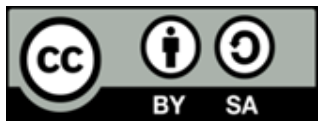

This is an open access article under the CC BY-SA license.

Copyright (C) Universitas Pendidikan Ganesha. All rights reserved.

\begin{abstract}
A B S T R A K
Kemampuan berkomunikasi secara lisan merupakan hal penting yang harus diajarkan sejak dini. Namun, permasalahan di lapangan menunjukkan bahwa kemampuan berbahasa lisan anak-anak masih sangat kurang dan media pembelajaran yang dapat digunakan untuk meningkatkan kemampuan berbahasa secara lisan belum pernah dikembangkan apalagi diterapkan. Oleh karena itu, penelitian ini bertujuan untuk menganalisis bagaimana pengembangan media gambar berseri untuk meningkatkan kemampuan berbahasa lisan anak kelompok $\mathrm{B}$ taman kanak-kanak. Penelitian ini menggunakan metode penelitian pengembangan model ADDIE, yang pada pelaksanaannya hanya sampai pada tahap pengembangan saja. Metode pengumpulan data yang dilakukan adalah pengumpulan data primer dengan instrumen penelitian adalah angket kuesioner. Subjek penelitian yaitu ahli berjumlah 4 orang. Teknik analisis data yang digunakan adalah analisis statistik kualitatif kuantitatif. Hasil penelitian menunjukkan bahwa media pembelajaran gambar berseri ini valid dan layak untuk diterapkan. Berdasarkan uji validitas materi dan media, dengan rata-rata nilai CVR 1,00 dan nilai CVI 1,00. Dapat disimpulkan bahwa pengembangan media gambar berseri untuk meningkatkan kemampuan berbahasa lisan anak usia dini memiliki 3 tahapan dan dinilai valid serta layak untuk diterapkan. Implikasi penelitian ini yaitu media yang dikembangkan dapat digunakan oleh guru dalam proses pembelajaran sehingga dapat meningkatkan kemampuan berbahasa lisan pada siswa usia dini.
\end{abstract}

A B S T R A C T

The ability to communicate orally is an important thing that must be taught from an early age. However, problems in the field show that children's oral language skills are still very lacking and learning media that can be used to improve oral language skills have never been developed before being implemented. Therefore, this study aims to analyze how the development of serial picture media to improve the oral language skills of group B kindergarten. This study uses the ADDIE model development research method, which in its implementation only reaches the development stage. The data collection method used is primary data collection with the research instrument being a questionnaire questionnaire. The research subject is the expert who reveals 4 people. The data analysis technique used is quantitative quantitative statistical analysis. The results showed that the serial picture learning media was valid and feasible to be applied based on the validity of the material and media, with an average CVR value of 1.00 and a CVI value of 1.00. It can be said that the development of serial image media to improve early childhood oral skills has 3 stages and is considered valid to be applied. The implication of this research is that the developed media can be used by teachers in the learning process so that they can improve oral language skills at an early age.

\section{Pendahuluan}

Pendidikan merupakan suatu keharusan bagi setiap individu, serta merupakan hak yang wajib untuk dipenuhi, karena pendidikan merupakan bagian dari proses memanusiakan manusia sekaligus sebagai bagian dari kegiatan untuk mengasah dan membentuk manusia menjadi jauh lebih baik, baik dari

Copyright (C) Universitas Pendidikan Ganesha. All rights reserved 
segi kognitif, psikomotor, maupun afektif (Jenilan, 2018; Musanna, Wibowo, \& Hastutiningsih, 2017; Setyawan, 2018). Dalam penerapannya, pendidikan di Indonesia dimulai dari tingkat anak usia dini hingga perguruan tinggi. Pendidikan anak usia dini ini biasanya berawal dari Taman Kanak-Kanak atau biasa disebut TK. Pendidikan yang didapat saat di bangku Taman Kanak-Kanak merupakan sebuah pendidikan yang ditunjukan untuk merangsang dalam membantu anak didik mengembangkan berbagai potensi baik fisik maupun psikis yang meliputi moral dan nilai-nilai agama, sosial emosional, kognitif, bahasa, fisik/motorik, kemandirian bahkan hingga kesenian (Apriyanti, 2019; Kurniati, Nur Alfaeni, \& Andriani, 2020; Lilawati, 2020). Pendidikan yang didapatkan di awal ini merupakan hal yang sangat penting bagi kehidupan mereka ke depannya. Pendidikan di bangku Taman-Kanak-Kanak merupakan sebuah kegiatan untuk membekali anak-anak melanjutkan jenjang ke pendidikan tingkat selanjutnya, pun juga sebagai sarana untuk mengembangkan pola pikir mereka selama masa sekolah di TK (Hanum, 2017; Rohmat, 2017). Lebih lanjut, pendidikan anak usia dini mutlak dibutuhkan dan proses pembelajarannya tidak bisa secara sembarangan dilakukan.

Namun, dalam realitas yang ditemukan di lapangan, pendidikan anak usia dini tidak diterapkan secara maksimal. Proses pendidikannya masih cenderung asal, bahkan tidak didukung oleh media pembelajaran yang mumpuni. Berdasarkan hasil observasi peneliti, terdapat beberapa pembelajaran pada anak usia dini yang kurang mendapat perhatian sehingga kemampuan anak juga tidak mengalami kemajuan, salah satunya merupakan pembelajaran berbahasa anak usia dini. Secara general, kemampuan berbahasa anak usia dini secara lisan masih sangat minim. Dalam berkomunikasi, mereka cenderung kurang adaptif, kurang bisa menyampaikan perasaan atau emosi mereka secara baik dan benar, serta masih memiliki berbagai kesulitan dalam pengucapan kata maupun dalam pelafalannya (Nuraeni, Maesaroh, \& Sumitra, 2019; Sumitra, Windarsih, Elshap, \& Jumiatin, 2019). Permasalahan ini ditemukan dalam pembelajaran di salah satu taman kanak-kanak. Observasi di Taman Kanak-Kanak Jaya Kumara Cau Belayu yang dilakukan oleh peneliti mengungkapkan media pembelajaran masih jarang digunakan untuk meningkatkan kemampuan berbahasa lisan pada anak. Guru masih cenderung menggunakan metode pembelajaran yang sifatnya monoton (model pembelajaran konvensional), dan media yang digunakan juga masih sangat terbatas. Penggunaan buku cerita bergambar yang sering dilakukan oleh guru di sekolah juga kurang optimal, mengingat siswa hanya akan fokus pada cerita sang guru, bukan pada bagaimana mereka harusnya memahami apa yang disampaikan. Hal ini mengakibatkan banyak dari siswa masih kurang baik dalam pengucapan kata/huruf, yang mengakibatkan artikulasi yang diucapkan anak kurang jelas, serta anak-anak kurang mampu untuk menyampaikan pemikiran, gagasan, perasaan, maupun emosi mereka secara jelas kepada orang lain.

Padahal, pendidikan anak usia dini secara khusus harus didesain sesuai dengan aspek perkembangan mereka. Pada tahap usia ini, aspek perkembangan bahasa merupakan salah satu aspek perkembangan yang penting untuk dikembangkan sebagai bekal melanjutkan pendidikan ke jenjang selanjutnya (Fitriani, Fajriah, \& Rahmita, 2019; Fitriani et al., 2020; Khotijah, 2016). Selain itu, perkembangan bahasa merupakan salah satu faktor terpenting dalam pertumbuhan dan perkembangan anak, karena bahasa memiliki ruang lingkup yang luas yang dapat digunakan untuk mengekspresikan perasaan, emosi seseorang terhadap lingkungan di sekitar. Perkembangan bahasa merupakan kemampuan anak berkomunikasi dengan menyimbolkan pikiran dan perasaan untuk menyampaikan makna kepada orang lain yang bersifat reseptif dan ekspresif (Indriastuti, 2017; Kurniawati, 2019; Sa'ida, 2018). Lebih lanjut, bahasa memberikan sumbangan yang pesat bagi perkembangan anak menjadi manusia dewasa. Dengan bantuan bahasa anak tumbuh dari organisme biologis menjadi pribadi dalam kelompok (Mulyaningtyas, 2019; Risnawati \& Nuraeni, 2019). Perkembangan bahasa yang dimiliki oleh anak bermula dari tingkat yang sederhana menuju ke tingkat yang kompleks. Hal itu dipengaruhi oleh tumbuh kembang pada anak seiring dengan pemahaman anak. Pengembangan kemampuan berbahasa pada anak usia dini bertujuan agar anak mampu mengungkapkan pikiran melalui bahasa sederhana secara tepat, yang dalam arti sederhana berarti mampu berkomunikasi (Indriastuti, 2017; Khotijah, 2016). Maka dari itu, perkembangan bahasa merupakan salah satu aspek pengembangan kemampuan dasar anak yang sangat penting, terutama dalam pengembangan bahasa lisan. Dengan demikian, maka penelitian untuk mengembangkan media pembelajaran baru yang sesuai dengan kebutuhan anak yang berkaitan dengan peningkatan kemampuan berbahasa lisan mutlak harus dilakukan.

Penggunaan media visual yang menarik dan berwarna-warni dinilai sangat tepat dan atraktif (Salfera, 2017; F. Setiawan, 2017). Salah satu media yang cukup atraktif bagi anak adalah gambar berseri. Media gambar berseri merupakan sebuah media dimana gambar yang ditampilkan saling berhubungan atau saling berkaitan antara gambar 1 dengan gambar seterusnya. Media gambar berseri adalah simbol yang mengungkapkan pesan tertentu untuk mengungkapkan suatu kehidupan manusia yang mendalam, disajikan secara bersambung atau berkesinambungan (Hidayah, Wahyuni, \& Hasnanto, 2020; Rizqi, 2018). Media gambar berseri termasuk media visual karena media gambar berseri hanya dapat dilihat saja. 
Melalui media gambar berseri, pendidik atau guru dapat melatih perkembangan bahasa pada anak, karena dengan menggunakan bantuan media ini anak bisa secara langsung melihat gambar kegiatan yang anak akan ceritakan. Gambar berseri memiliki kelebihan, di mana anak akan lebih mudah untuk menceritakan kejadian atau peristiwa yang ada digambar secara lisan. Menggunakan media gambar berseri dalam pembelajaran akan dapat melatih keterampilan anak dalam berbicara, sehingga bahasa lisan yang dimiliki oleh anak berkembang (Diningtias, 2019; Suhandra, 2018; Swarastuti, 2019). Dengan demikian, media gambar berseri dapat menjadi salah satu alternatif media yang bisa digunakan dalam meningkatkan kemampuan berbahasa lisan pada anak.

Temuan penelitian sebelumnya juga menyatakan bahwa dapat memudahkan siswa dalam memahami materi pembelajaran (Arif \& Samidjo, 2018; Dames, Koeswanti, \& Radia, 2019). Temuan penelitian lainnya juga menyatakan bahwa media gambar dapat menarik perhatian siswa dalam belajar (Mardati, Asih, \& Wangit, 2015; Priani, Manuaba, \& Darsana, 2019). Belum adanya kajian mengenai media gambar berseri dapat meningkatkan kemampuan berbahasa pada anak usia dini. Kelebihan media gambar yang akan dikembangkan yaitu gambar yang disajikan menarik mengenai kegiatan yang biasa dilakukan anak sehari-hari sehingga memudahkan anak dalam memahami materi. Kebaharuan dalam penelitian ini terletak pada sasaran penelitian berupa anak-anak kelompok B taman kanak-kanak, serta pada keterampilan berbahasa yang diajarkan dengan fokus hanya kepada keterampilan berbahasa lisan. Tujuan penelitian ini yaitu untuk menciptakan media gambar berseri dapat meningkatkan kemampuan berbahasa pada anak usia dini. Diharapkan media yang dikembangkan dapat merangsang siswa dalam belajar sehingga dapat merangsang kemampuan berbahasa pada sisa.

\section{Metode}

Penelitian ini menggunakan jenis penelitian pengembangan atau Research and Development dengan pendekatan campuran yaitu kualitatif dan kuantitatif. Dalam penelitian pengembangan ini, model penelitian yang digunakan yaitu model pengembangan ADDIE (Analysis, Design, Development, Implementation, Evaluation) (Nababan, 2020). Namun pada penelitian ini, tahap implementasi dan evaluasi tidak dilakukan karena situasi pandemi COVID-19.

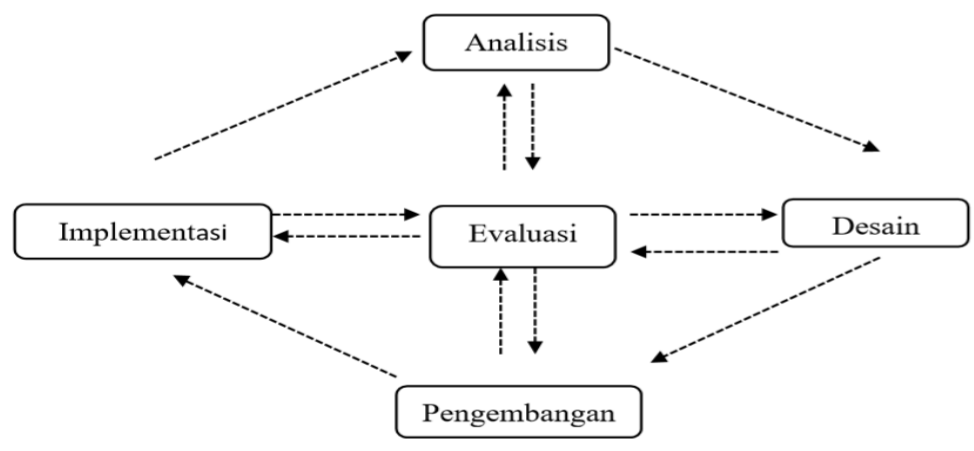

Gambar 1. Desain Penelitian Pengembangan Model ADDIE

(Nababan, 2020)

Dalam penelitian ini, metode pengumpulan data yang dilakukan yaitu metode pengumpulan data primer. Subjek penelitian ini adalah media gambar berseri dengan responden ahli media berjumlah 2 orang dan ahli materi yang berjumlah 2 orang. Teknik yang digunakan dalam mengumpulkan data pada penelitian ini yaitu angket. Angket digunakan untuk mengumpulkan data yang berkaitan dengan validasi ahli. Instrument yang digunakan dalam mengumpulkan data yaitu kuesioner. Adapun kisi-kisi kuesioner yang digunakan tersaji pada Tabel 1 dan Tabel 2.

Tabel 1. Kisi-Kisi Ahli Materi Pembelajaran

\begin{tabular}{|c|c|c|}
\hline No & Variabel & Indikator \\
\hline 1 & Tujuan & $\begin{array}{l}\text { 1. Kesesuaian media gambar berseri untuk meningkatkan kemampuan } \\
\text { berbahasa lisan anak }\end{array}$ \\
\hline 2 & Isi Materi & $\begin{array}{l}\text { 2. Kesesuaian media gambar berseri untuk mendukung meningkatkan } \\
\text { kemampuan berbahasa lisan anak } \\
\text { 3. Kesesuaian kegiatan yang di susun pada gambar berseri sesuai } \\
\text { dengan urutannya }\end{array}$ \\
\hline
\end{tabular}




\begin{tabular}{cll}
\hline No & \multicolumn{1}{c}{ Variabel } & \multicolumn{1}{c}{ Indikator } \\
\hline 3 & Kejelasan Materi & 4. Kejelasan informasi terlihat pada ilustrasi gambar \\
4 & Motivasi & 5. Kesesuaian materi untuk memotivasi belajar anak \\
\hline & &
\end{tabular}

Tabel 2. Kisi-Kisi Ahli Media Pembelajaran

\begin{tabular}{|c|c|c|}
\hline No & Variabel & Indikator \\
\hline 1 & $\begin{array}{l}\text { Feasibility } \\
\text { (Kelayakan) }\end{array}$ & $\begin{array}{l}\text { 1. Kemenarikan kemasan media gambar berseri } \\
\text { 2. Kemenarikan warna pada gambar berseri } \\
\text { 3. Kemenarikan gambar pada media gambar berseri. } \\
\text { 4. Produk praktis dan mudah digunakan } \\
\text { 5. Dapat digunakan dalam jangka waktu yang lama. }\end{array}$ \\
\hline 2 & Komposisi & $\begin{array}{l}\text { 6. Produk menggunakan bahan-bahan yang aman dan tidak } \\
\text { membahayakan }\end{array}$ \\
\hline 3 & Teks & $\begin{array}{l}\text { 7. Kesesuaian dalam pemilihan ukuran tulisan } \\
\text { 8. Kesesuaian dalam pemilihan jenis huruf }\end{array}$ \\
\hline 4 & Gambar & $\begin{array}{l}\text { 9. Kejelasan bentuk gambar } \\
\text { 10. Ketepatan ukuran gambar }\end{array}$ \\
\hline 5 & Warna & $\begin{array}{l}\text { 11.Ketepatan pemilihan warna pada background } \\
\text { 12.Kesesuaian warna tulisan dengan background }\end{array}$ \\
\hline
\end{tabular}

(Febiharsa \& Djuniadi, 2018)

Analisis yang digunakan pada penelitian ini yaitu menggunakan analisis statistik kualitatif dan kuantitatif. Analisis statistik kualitatif digunakan dalam mengelola data yang terdiri dari tanggapan, kritik, dan saran yang didapat dari hasil review. Hasil dari review kemudian dianalisis dengan cara mengelompokkan data kualitatif komentar dan saran yang didapatkan dari hasil review. Setelah itu hasil dari analisis kemudian digunakan untuk memperbaiki media yang dikembangkan. Sedangkan pada bagian analisis statistik kuantitatif digunakan untuk mendeskripsikan rata-rata skor dari setiap ahli yang terkait dengan media yang dikembangkan. Ketika skor sudah didapat dari penilai, kemudian akan dirata-rata untuk mengetahui validitas media gambar berseri dengan menggunakan rumus Content Validity Ratio (CVR). Setelah mengidentifikasi setiap sub pertanyaan instrumen dengan menggunakan CVR, maka selanjutnya yaitu melakukan perhitungan CVI. Dalam menghitung nilai rata-rata dapat digunakan CVI dari nilai keseluruhan CVR (Lawshe, 1985).

\section{Hasil dan Pembahasan}

Penelitian pengembangan ini dilakukan untuk mengembangkan sebuah produk media pembelajaran untuk meningkatkan kemampuan berbahasa lisan anak. Produk berupa gambar berseri yang dikemas menyerupai kalender. Produk media ini dapat digunakan oleh anak secara individual atau secara berkelompok. Pengembangan media gambar berseri ini menggunakan model ADDIE yang memiliki 5 tahapan. Yang pertama adalah tahap analisis. Pada tahap analisis ini, yang dilakukan oleh peneliti adalah menganalisis permasalahan terkait media pembelajaran di sekolah, khususnya mengenai media pembelajaran yang berkaitan untuk meningkatkan kemampuan berbahasa lisan anak. Berdasarkan dari hasil analisis yang dilakukan ditemukan hasil bahwa kemampuan berbahasa lisan anak masih sangat kurang serta media pembelajaran yang digunakan masih belum bervariasi dalam meningkatkan kemampuan berbahasa lisan anak. Salah satunya ketika proses pembelajaran guru lebih sering menggunakan media buku cerita bergambar untuk meningkatkan kemampuan berbahasa lisan pada anak, di mana ketika menggunakan buku cerita bergambar anak akan lebih fokus untuk mendengarkan cerita yang disampaikan oleh guru, sehingga kurang efektif dalam meningkatkan kemampuan berbahasa lisan pada anak, karena anak tidak bisa secara langsung untuk bercerita menggunakan bahasanya sendiri. Selain itu juga, anak-anak lebih tertarik dengan media visual, yaitu sebuah media yang bisa dinikmati lewat panca indera mata. Berdasarkan hasil analisis tersebut, dirancanglah media gambar berseri yang sesuai dengan permasalahan dan kebutuhan untuk mendukung dalam meningkatkan kemampuan berbahasa lisan pada anak kelompok B taman kanak-kanak.

Kedua adalah tahap perancangan atau desain. Sebelum merancang sebuah media, peneliti terlebih dahulu merumuskan tujuan pembelajaran yang ingin dicapai untuk meningkatkan perkembangan pada anak. Selanjutnya, menentukan tema kegiatan yang akan dibuatkan gambar berseri dan tema kegiatan yang akan digunakan adalah "Kegiatan Bobi di Pagi Hari". Setelah itu, barulah mulai merancang 
media gambar berseri sesuai dengan analisis yang dilakukan sebelumnya. Dalam tahap desain pembuatan media gambar berseri ini, terlebih dahulu mengumpulkan gambar-gambar kegiatan yang berhubungan dengan tema yang sudah ditentukan mulai dari kegiatan anak bangun pagi, kegiatan anak membersihkan tempat tidurnya, kegiatan anak mandi, kegiatan anak memakai seragam sekolah, kegiatan anak berpamitan dengan orang tuanya, sampai dengan kegiatan terakhir anak pergi ke sekolah bersama temantemannya. Setelah semua gambar sudah terkumpul, dimulailah proses editing gambar tersebut untuk digabungkan dengan background, warna, tulisan dan nomor menggunakan aplikasi CorelDraw. Untuk ukuran dari media ini adalah dengan panjang $30 \mathrm{~cm}$ dan lebar 21,5 cm dengan format kertas landscape satu kertas berisikan gambar full 1 kegiatan. Ketika semua proses editing selesai barulah semua gambargambar itu dicetak menggunakan kertas Art Paper dan disusun secara berurutan mulai dari cover, kegiatan 1 sampai dengan kegiatan nomor 6 kemudian dirangkai dalam bentuk kalender.

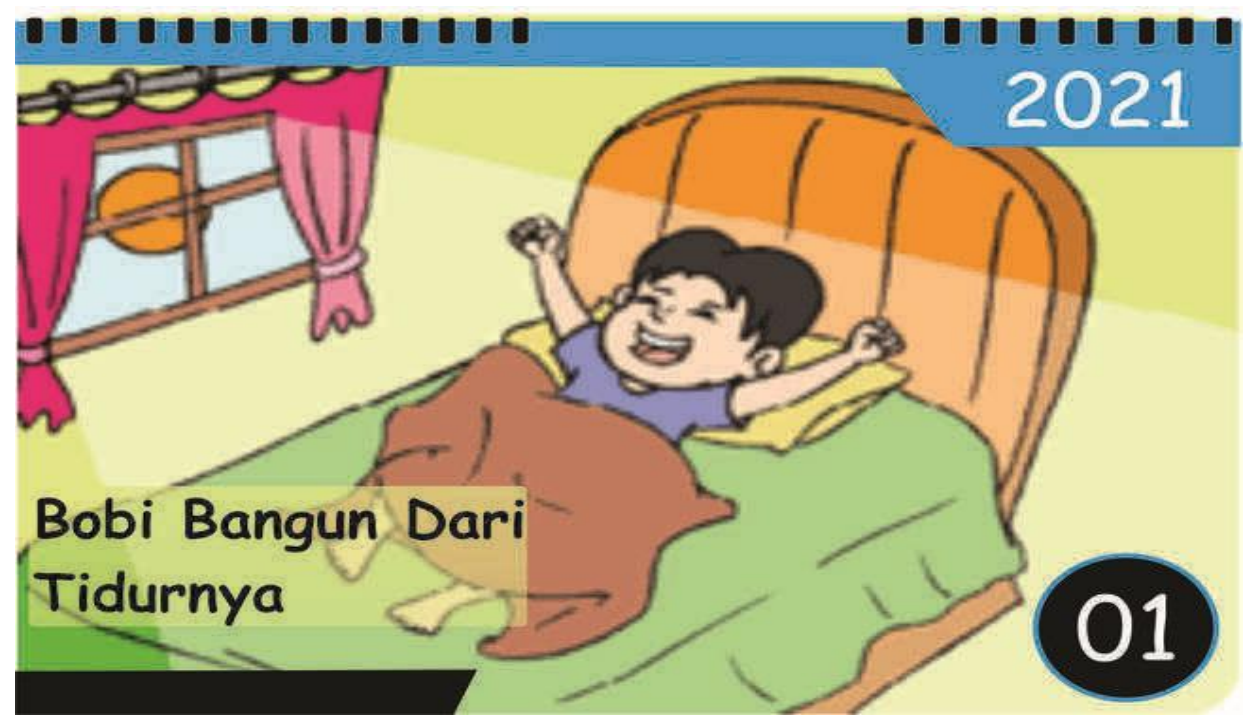

Gambar 2. Contoh Gambar Berseri dengan Tema Bobi Bangun Pagi

Langkah ketiga adalah tahap pengembangan. Pada tahap pengembangan ini hal yang dilakukan yaitu mengembangkan media yang disesuaikan dengan rancangan awal yang dibuat. Setelah media gambar berseri selesai dikembangkan, barulah proses selanjutnya yang dilakukan yaitu melakukan penilaian yang dilakukan oleh dua ahli dalam media serta dua ahli materi pembelajaran. Hasil validasi dari 2 ahli materi pembelajaran menunjukkan hasil CVR dan CVI 1.00 yang berarti valid. Sedangkan hasil validasi ahli media pembelajaran juga menunjukkan hasil CVR dan CVI 1.00 yang berarti valid. Dapat disimpulkan bahwa media yang dikembangkan valid dan layak diterapkan dalam proses pembelajaran. Adapun masukan dan saran yang diberikan oleh ahli media pembelajaran yaitu sebagai berikut.

Tabel 3. Komentar dan Hasil Perbaikan Media Gambar Berseri

\begin{tabular}{|c|c|}
\hline Komentar dan Saran & Hasil Perbaikan \\
\hline $\begin{array}{l}\text { Judul pada cover pakai huruf kapital semua, teks } \\
\text { pada gambar disesuaikan dengan EYD, pada cover } \\
\text { diberikan identitas pengembangan dan logo } \\
\text { universitas serta pada nomor halaman diletakan di } \\
\text { kanan bawah. }\end{array}$ & $\begin{array}{l}\text { Judul pada cover sudah disesuai dengan catatan } \\
\text { yang diberikan oleh ahli, teks penulisan pada } \\
\text { gambar sudah disesuaikan, cover sudah diberi } \\
\text { kata pengembangan dan tambahan logo } \\
\text { universitas, dan nomor halaman sudah diletakan } \\
\text { di kanan bawah gambar. }\end{array}$ \\
\hline
\end{tabular}

Background yang tidak mendukung dihapus, penulisan setiap penjelasan masing-masing gambar harus disesuaikan, gambar pada nomor 6 diganti dengan yang lain.

Background sudah disesuaikan, penulisan gambar sudah disamakan antara gambar satu dengan yang lainnya, dan gambar nomor 6 sudah diganti.

Setelah mendapatkan komentar dan hasil perbaikan, berikut contoh gambar yang sudah diperbaiki sesuai dengan saran dari para ahli. 


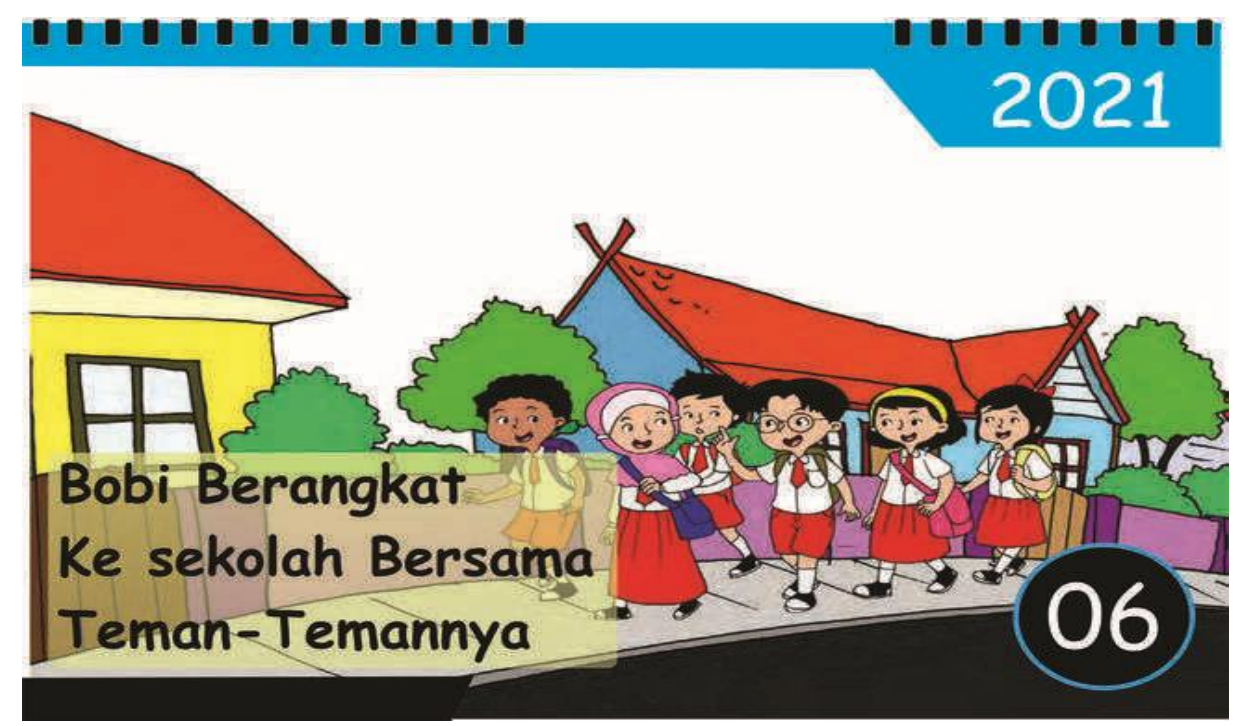

Gambar 3. Contoh Gambar Berseri yang Sudah Diperbaiki

Tahap keempat sesuai model pengembangan ADDIE adalah tahap implementasi. Pada tahap implementasi media gambar berseri untuk meningkatkan kemampuan berbahasa lisan pada penelitian ini tidak dapat diujicobakan pada anak Kelompok B Taman Kanak-Kanak, karena pada situasi darurat covid19 ini tidak memungkinkan untuk diujicobakan kepada anak, sehingga peneliti hanya sampai pada validasi ahli materi dan ahli media saja. Tahap terakhir yaitu tahap evaluasi. Pada tahap evaluasi ini, merupakan sebuah tahapan penyempurnaan akhir dari media yang dikembangkan setelah melalui beberapa tahapan uji coba serta merupakan umpan balik dalam proses pengembangan. Pada tahap evaluasi ini juga tidak dapat diuji cobakan pada proses pembelajaran di Taman Kanak-Kanak, karena situasi darurat covid-19.

Media gambar berseri dinilai layak dan valid oleh ahli, baik ahli media maupun ahli materi. Hal ini menunjukkan bahwa media gambar berseri yang dikembangkan sudah sesuai dengan tahapan pengembangan, materi dan desain media yang baik, dan dinilai dapat diterapkan dalam pembelajaran untuk anak usia dini. Hal ini sesuai dengan beberapa penelitian bahwa dalam pengembangan media pembelajaran yang perlu digarisbawahi adalah uji validitas seperti materi pembelajaran dan media pembelajaran untuk memastikan sesuai dengan pembelajaran yang ada di sekolah dan perkembangan psikologi anak. Selain itu, sebelum uji coba atau implementasi, kelayakan media pembelajaran juga harus dinilai oleh para ahli, sehingga ketika uji coba dilaksanakan nantinya media sudah dalam kondisi siap dan layak diimplementasikan (Indriastuti, 2017; Patriani \& Kusumaningrum, 2020; Radita, 2018). Kemudian, jika dikaitkan dengan tahapan pengembangan ADDIE, dari 5 tahap pengembangan, tidak perlu 5 tahap dilakukan semua jika dalam kondisi yang tidak memungkinkan (Koedoes, Abubakar, Nadzirin, \& Nur, 2020; Lestari, Sutama, \& Utama, 2019; Nababan, 2020; Patriani \& Kusumaningrum, 2020; Rispantyo, Anita Trisiana, 2019). Hal ini sesuai dengan prinsip penelitian yaitu kemampuan peneliti dan juga situasi lingkungan. Di masa pandemi covid-19 tidak akan memungkinkan terjadinya tatap muka dengan siswa di sekolah, sehingga tahap 4 dan 5 bisa dihilangkan.

Hasil dari penelitian, terdapat dua hal yang perlu untuk dibahas, yaitu terkait dengan materi pembelajaran dan media pembelajaran. Pertama, terkait dengan materi pembelajaran. Materi pembelajaran yang digunakan pada pengembangan media gambar berseri berfokus pada bagaimana meningkatkan kemampuan berbahasa lisan anak. Fokus pembahasan materi yang diberikan menggunakan bahasa sehari-hari dengan kegiatan sehari-hari seperti bangun tidur, berdoa, bermain, dan banyak lagi. Kegiatan sehari-hari ini jauh lebih familiar bagi anak, sehingga anak akan memiliki gambaran mengenai apa yang harus diucapkan atau dijelaskan terkait gambar yang diberikan,. Dengan demikian, maka anak-anak akan lebih mudah menyampaikannya kepada orang lain secara lisan sehingga kemampuan berbahasa lisannya secara tidak langsung akan meningkat jika terus dibiasakan. Hal ini sesuai dengan penelitian-penelitian beberapa ahli yang menyebutkan bahwa pembelajaran pada anak usia dini sebisa mungkin melibatkan hal-hal yang berhubungan dengan kesehariannya atau kegiatan yang disukainya, sehingga anak akan lebih percaya diri dan lebih mudah memahami apa yang disampaikan (Nurlaili, 2018; Sari \& Setiawan, 2012; A. Setiawan, Praherdhiono, \& Suthoni, 2019). Selain itu, karena anak-anak semakin mudah memahami, maka perbendaharaan kosakata mereka juga akan semakin 
banyak dan meningkat. Hal ini juga berdampak positif terhadap hasil pembelajaran nantinya (Cristy, 2017; Khotijah, 2016; Nuraeni et al., 2019; Sa'ida, 2018; Salfera, 2017).

Kedua adalah media pembelajaran. Media pembelajaran yang unik dan menarik dari segi desain juga akan mampu menarik anak-anak untuk memberikan perhatian lebih (Apriyanti, 2019; Ayu \& Junaidah, 2019; F. H. Setyawan, 2016). Media pembelajaran dengan visual yang menarik secara tidak langsung membuat anak-anak akan lebih termotivasi untuk belajar sehingga kemampuannya nanti akan meningkat dan hasil pembelajarannya akan jauh lebih baik bila dibandingkan tanpa media (Diningtias, 2019; Nurmadiah, 2016; Zaini \& Dewi, 2017). Berdasarkan hasil temuan, media gambar berseri memiliki desain yang menarik dan kata-kata yang mudah dipahami, sehingga anak-anak nantinya akan jauh lebih termotivasi belajar dan mampu meningkatkan kemampuan berbahasa lisannya. Hal ini terbukti dari hasil penilaian ahli media yang menyatakan bahwa media gambar berseri valid dan layak diterapkan.

Temuan penelitian sebelumnya juga menyatakan bahwa media gambar dapat memudahkan siswa dalam memahami materi pembelajaran (Handayani \& Abadi, 2020; Pujayanti, Murda, \& Wibawa, 2013). Temuan penelitian lainnya juga menyatakan bahwa media gambar dapat meningkatkan hasil belajar siswa (Aprinawati, 2017; Umbara, Sujana, \& Negara, 2020). Dapat disimpulkan bahwa media gambar dapat meningkatkan semangat dan hasil belajar siswa. Kelebihan media yang dikembangkan yaitu gambar yang disajikan menarik mengenai kegiatan yang biasa dilakukan anak sehari-hari sehingga memudahkan anak dalam memahami materi. Keterbatasan penelitian ini hingga sampai uji validitas media gambar, tetapi tetap dapat digunakan dalam proses pembelajaran karena dapat memudahkan anak dalam belajar berbahasa lisan. Penelitian ini juga berdampak pada kemampuan berbahasa lisan pada anak usia dini meningkat. Implikasi penelitian ini yaitu media gambar berseri yang dikembangkan dapat meningkatkan semangat dan motivasi belajar siswa sehingga dapat meningkatkan kemampuan berbahasa lisan pada anak usia dini.

\section{Simpulan}

Media gambar berseri mendapatkan kategori sangat baik sehingga dapat digunakan dalam proses pembelajaran. Media gambar berseri juga dapat meningkatkan semangat anak dalam belajar. Direkomendasikan kepada guru untuk menggunakan media gambar berseri dalam mengajar sehingga dapat meningkatkan antusias, sehingga berdampak pada peningkatan kemampuan berbahasa lisan pada anak usia dini.

\section{Daftar Rujukan}

Aprinawati, I. (2017). Penggunaan Media Gambar Seri Untuk Meningkatkan Kemampuan Berbicara Anak Usia Dini. Jurnal Obsesi: Jurnal Pendidikan Anak Usia Dini, 1(1). https://doi.org/https://doi.org/10.31004/obsesi.v1i1.33.

Apriyanti, H. (2019). Pemahaman Orang Tua Terhadap Pentingnya Pendidikan Anak Usia Dini. Education. Education Journal: Journal Educational Research and Development, 3(1). https://doi.org/10.31537/ej.v3i1.137.

Arif, L., \& Samidjo, S. (2018). Hubungan Antara Sikap Belajar Dan Motivasi Belajar Kejuruan Dengan Hasil Belajar Gambar Teknik. Jurnal Taman Vokasi, 6(1). https://doi.org/http://dx.doi.org/10.30738/jtv.v6i1.2865.

Ayu, S. M., \& Junaidah, J. (2019). Pengembangan Akhlak pada Pendidikan Anak Usia Dini. AL-IDARAH: Jurnal Kependidikan Islam, 8(2). https://doi.org/10.24042/alidarah.v8i2.3092.

Cristy, Y. (2017). Perkembangan Bahasa Pada Anak Usia Dini. Jurnal Ilmiah Pendidikan Bahasa Dan Sastra Indonesia, 3(2).

Dames, I., Koeswanti, H. D., \& Radia, E. H. (2019). Penerapan Model Examples Non Examples Berbantuan Media Gambar Untuk Meningkatkan Hasil Belajar Pada Tema 1 Siswa Kelas 5 SDN Sidorejo Lor 05. Jurnal Basicedu, 3(1). https://doi.org/https://doi.org/10.31004/basicedu.v3i2.59.

Diningtias, R. dan S. M. (2019). Metode Bercerita Berbasis Media Gambar Berseri Terhadap Kemampuan Pengenalan Konsep Waktu pada Anak Tunagrahita Ringan. Jurnal Pendidikan Khusus, 12(03).

Febiharsa, D., \& Djuniadi, D. (2018). Pengembangan Media Pembelajaran Interaktif 3 Dimensi untuk Pembelajaran Materi Pengenalan Lingkungan Pada Anak Usia Dini di Indonesia. Journal of Studies in Early Childhood Education (J-SECE), 1(1). https://doi.org/10.31331/sece.v1i1.590.

Fitriani, D., Fajriah, H., \& Rahmita, W. (2019). Media Belajar Big Book dalam Mengembangkan Kemampuan Berbahasa Reseptif Anak Usia Dini. Jurnal Obsesi: Jurnal Pendidikan Anak Usia Dini, 4(1). https://doi.org/10.31004/obsesi.v4i1.197.

Fitriani, D., Fajriah, H., Rahmita, W., Islam AnakUsia Dini, P., Islam Negeri Ar-Raniry, U., Aceh, B., \& Kanak- 
kanak Dharma Wanita, T. (2020). Jurnal Obsesi : Jurnal Pendidikan Anak Usia Dini Media Belajar Big Book dalam Mengembangkan Kemampuan Berbahasa Reseptif Anak Usia Dini. Obsesi.or.Id, $4(1)$.

Handayani, R., \& Abadi, I. B. G. S. (2020). Pengaruh Model Pembelajaran Langsung Berbantuan Media Gambar Terhadap Kompetensi Pengetahuan Matematika Siswa Kelas IV SD. Mimbar Ilmu Undiksha, 25(1), 120-131. https://doi.org/http://dx.doi.org/10.23887/mi.v25i1.24767.

Hanum, R. (2017). Evaluasi Pendidikan Anak Usia Dini. Pionir: Jurnal Pendidikan, 6(2).

Hidayah, N., Wahyuni, R., \& Hasnanto, A. T. (2020). Pengembangan Media Pembelajaran Gambar Berseri Berbasis Pop-Up Book Untuk Meningkatkan Keterampilan Menulis Narasi Bahasa Indonesia. Jurnal Pendidikan Dan Pembelajaran Dasar, 7(1).

Indriastuti, F. (2017). Kontribusi Pemanfaatan Media Audio Aksi Terhadap Pengembangan Kemampuan Berbahasa Pada Anak Usia Dini. Jurnal Kwangsan, 5(1). https://doi.org/10.31800/jtpk.v5n1.p51-63.

Jenilan, J. (2018). FILSAFAT PENDIDIKAN. EL-AFKAR : Jurnal Pemikiran Keislaman Dan Tafsir Hadis, 7(1). https://doi.org/10.29300/jpkth.v7i1.1588.

Khotijah. (2016). Strategi Pengembangan Bahasa pada Anak Usia Dini. Elementary, 2(2). Retrieved from https://e-journal.metrouniv.ac.id/index.php/elementary/article/view/strategi-pengembahanbahasa-anak-usia-dini

Koedoes, Y. A., Abubakar, S. R., Nadzirin, M., \& Nur, A. (2020). Solusi Pembelajaran Anak Usia Dini pada Masa Pandemi Covid-19. Jurnal Pengabdian Masyarakat Ilmu Terapan, 2(2). Retrieved from http://ojs.uho.ac.id/index.php/JPMIT/article/view/14856.

Kurniati, E., Nur Alfaeni, D. K., \& Andriani, F. (2020). Analisis Peran Orang Tua dalam Mendampingi Anak di Masa Pandemi Covid-19. Jurnal Obsesi: Jurnal Pendidikan Anak Usia Dini, 5(1), 241. https://doi.org/10.31004/obsesi.v5i1.541.

Kurniawati, D. (2019). Keefektifan Pengajaran Kosakata Bahasa Inggris Pada Anak Sekolah Dasar Dengan Menggunakan Flash Card. Jurnal Pendidikan Dan Pembelajaran Dasar, 2(2), 59. https://doi.org/10.37484/manajemen_pelayanan_hotel.v2i2.40.

Lawshe, C. H. (1985). Inferences From Personnel Tests and Their Validity. Journal of Applied Psychology, 70(1). https://doi.org/10.1037/0021-9010.70.1.237.

Lestari, N. M. C. P., Sutama, I. M., \& Utama, I. D. G. B. (2019). PENGEMBANGAN MEDIA PEMBELAJARAN VISUAL BAGI PEBELAJAR BIPA PEMULA DI UNDIKSHA. Jurnal Pendidikan Bahasa Dan Sastra Indonesia Undiksha, 8(1). https://doi.org/10.23887/jjpbs.v8i1.20535.

Lilawati, A. (2020). Peran Orang Tua dalam Mendukung Kegiatan Pembelajaran di Rumah pada Masa Pandemi. Jurnal Obsesi: Jurnal Pendidikan Anak Usia Dini, 5(1), 549. https://doi.org/10.31004/obsesi.v5i1.630.

Mardati, Asih, \& Wangit. (2015). Pengembangan Media Permainan Kartu Gambar Dengan Teknik Make A Match Untuk Kelas 1 SD. Jurnal Prima Edukasia, 3(2), 120- 132. https://doi.org/https://doi.org/10.21831/jpe.v3i2.6532.

Mulyaningtyas, R. (2019). Stimulasi Dalam Memaksimalkan Kemampuan Berbahasa Anak Usia Dini. Martabat: Jurnal Perempuan Dan Anak, 3(1). https://doi.org/10.21274/martabat.2019.3.1.121140.

Musanna, A., Wibowo, U. B., \& Hastutiningsih, A. D. (2017). INDIGENISASI PENDIDIKAN: Rasionalitas Revitalisasi Praksis Pendidikan Ki Hadjar Dewantara. Jurnal Pendidikan Dan Kebudayaan, 2(1). https://doi.org/10.24832/jpnk.v2i1.529.

Nababan, N. (2020). Pengembangan Media Pembelajaran Berbasis Geogebra Dengan Model Pengembangan Addie Di Kelas Xi Sman 3 Medan. Jurnal Inspiratif, 6(1).

Nuraeni, S., Maesaroh, A., \& Sumitra, A. (2019). Optimalisasi Keterampilan Berbicara Untuk Meningkatkan Keyakinan Diri Anak Usia Dini Di Tk Baiturrahman Kabupaten Bandung. CERIA (Cerdas Energik Responsif Inovatif Adaptif), 2(4). https://doi.org/10.22460/ceria.v2i4.p166-172.

Nurlaili, N. (2018). Sumber Belajar Dan Alat Permainan Untuk Pendidikan Anak Usia Dini. Al Fitrah: Journal Of Early Childhood Islamic Education, 2(1). https://doi.org/10.29300/alfitrah.v2i1.1518.

Nurmadiah, N. (2016). Strategi Pembelajaran Anak Usia Dini. Al-Afkar: Jurnal Keislaman \& Peradaban, 3(1). https://doi.org/10.28944/afkar.v3i1.101.

Patriani, R. P., \& Kusumaningrum, I. (2020). Pengembangan Media Pembelajaran Interaktif Berbasis Android Untuk Pembelajaran Teknik Animasi 2 Dan 3 Dimensi Kelas XI Sekolah Menengah Kejuruan. Jurnal Penelitian IPTEKS, 5(2). https://doi.org/10.32528/ipteks.v5i2.3651.

Priani, I., Manuaba, I. B. S., \& Darsana, I. W. (2019). Pengaruh Model Problem Based Learning (PBL) Berbantuan Media Gambar Terhadap Hasil Belajar IPA Siswa Kelas V Gugus III Kuta Utara Tahun Pelajaran $2017 / 2018$. Mimbar $P G S D$, $7(1)$. 
https://doi.org/http://dx.doi.org/10.23887/jjpgsd.v7i1.16972.

Pujayanti, P., Murda, I. N., \& Wibawa, I. M. C. (2013). Pengaruh Model Pembelajaran Course Review Horay Berbantuan Media Gambar Terhadap Hasil Belajar Ipa Siswa Kelas Iv Sd Gugus Viii Munduk. MIMBAR PGSD Undiksha, 1(1). https://doi.org/http://dx.doi.org/10.23887/jjpgsd.v1i1.1341.

Radita, N. (2018). Pengembangan Sistem Pembelajaran dalam Jaringan pada Materi Teori Graph. MUST: Journal of Mathematics Education, Science and Technology, 3(1). https://doi.org/10.30651/must.v3i1.1463.

Risnawati, A., \& Nuraeni, L. (2019). Meningkatkan Kemampuan Berbahasa Sunda Anak Usia Dini Melalui Kegiatan Rebo Nyunda Di Pendidikan Anak Usia Dini. CERIA (Cerdas Energik Responsif Inovatif Adaptif), 2(5). https://doi.org/10.22460/ceria.v2i5.p243-250.

Rispantyo, Anita Trisiana, S. \&. (2019). Implementasi Pendidikan Karakter Dalam Pendidikan Kewarganegaraan Sebagai Inovasi Pengembangan Di Era Media Digital Dan Revolusi Industri 4.0. Jurnal Global Citizen: Jurnal Ilmiah Kajian Pendidikan Kewarganegaraan, 7(1). https://doi.org/10.33061/jgz.v7i1.3059.

Rizqi, M. R. (2018). Peran Media Gambar Berseri Dalam Meningkatkan Motivasi Kemampuan Menulis Karangan Bahasa Arab. El-Ibtikar. EL-IBTIKAR: Jurnal Pendidikan Bahasa Arab, 7(2). https://doi.org/10.24235/ibtikar.v7i2.3363.

Rohmat, R. (2017). Manajemen Pendidikan Anak Usia Dini. YINYANG: Jurnal Studi Islam, Gender Dan Anak, 12(2). https://doi.org/10.24090/yinyang.v12i2.2017.pp299-325.

Sa'ida, N. (2018). Bahasa Sebagai Salah Satu Sistem Kognitif Anak Usia Dini. Pedagogi : Jurnal Anak Usia Dini Dan Pendidikan Anak Usia Dini, 4(2). https://doi.org/10.30651/pedagogi.v4i2.1937.

Salfera, N. (2017). Meningkatkan Kemampuan Menulis Teks Eksplanasi Dengan Menggunakan Media Gambar Berseri Pada Siswa Kelas VII. Jurnal EDUCATIO: Jurnal Pendidikan Indonesia, 3(2). https://doi.org/10.29210/12017295.

Sari, K. M., \& Setiawan, H. (2012). Kompetensi Pedagogik Guru dalam Melaksanakan Penilaian Pembelajaran Anak Usia Dini. Jurnal Obsesi: Jurnal Pendidikan Anak Usia Dini, 4(2). https://doi.org/https://doi.org/10.31004/obsesi.v4i2.478.

Setiawan, A., Praherdhiono, H., \& Suthoni, S. (2019). Penggunaan Game Edukasi Digital Sebagai Sarana Pembelajaran Anak Usia Dini. JINOTEP (Jurnal Inovasi Dan Teknologi Pembelajaran) Kajian Dan Riset Dalam Teknologi Pembelajaran, 6(1). https://doi.org/10.17977/um031v6i12019p039.

Setiawan, F. (2017). Upaya Meningkatkan Keterampilan Menulis Karangan Siswa Kelas Iv Sekolah Dasar Dengan Menggunakan Media Gambar Berseri. ELSE (Elementary School Education Journal), 1(1).

Setyawan, A. A. (2018). Pendidikan Sebagai Proses Humanisasi (Studi Tentang Pendidikan Humaniora di SMA Seminari Menengah Mertoyudan Magelang, Jawa Tengah). Jurnal HUMMANSI (Humaniora, Manajemen, Akuntansi), 1(1). https://doi.org/10.33488/1.jh.2018.1.50.

Setyawan, F. H. (2016). Meningkatkan Kemampuan Berbahasa Anak Usia Dini Melalui Model Pembelajaran Audio Visual Berbasis Android. Jurnal PG-PAUD Trunojoyo, 3(2).

Suhandra, I. R. (2018). Pemanfaatan media gambar berseri untuk memperkaya kemampuan menulis naratif bahasa inggris siswa kelas IX MTS NW Nurul Wathon Pengembur Lombok Tengah. $\begin{array}{llll}\text { TRANSFORMASI: Jurnal Masyarakat, } & \text { 14(1). }\end{array}$ https://doi.org/10.20414/transformasi.v14i1.576.

Sumitra, A., Windarsih, C. A., Elshap, D. S., \& Jumiatin, D. (2019). Meningkatkan Kemampuan Mengenal Huruf Pada Anak Usia Dini Melalui Metode Bercerita Menggunakan Boneka Jari. Tunas Siliwangi : Jurnal Program Studi Pendidikan Guru PAUD STKIP Siliwangi Bandung, 6(1).

Swarastuti, A. (2019). The Impact Of Picture Series Towards Students' Ability In Writing Narrative Text. Edukasi Lingua Sastra, 17(1). https://doi.org/10.47637/elsa.v17i1.108.

Umbara, I. A. A. P., Sujana, I. W., \& Negara, I. G. A. O. (2020). Model Pembelajaran Problem Based Learning Berbantuan Media Gambar Seri BerpengaruhTerhadap Kompetensi Pengetahuan IPS Siswa. Jurnal Mimbar Ilmu, 25(2), 13-25. https://doi.org/http://dx.doi.org/10.23887/mi.v25i2.25154.

Zaini, H., \& Dewi, K. (2017). Pentingnya Media Pembelajaran Untuk Anak Usia Dini. Raudhatul Athfal: Jurnal Pendidikan Islam Anak Usia Dini, 1(1). https://doi.org/10.19109/ra.v1i1.1489. 